\title{
Pengaruh Kemandirian Belajar Terhadap Hasil Belajar Matematika Siswa Kelas VIII SMP
}

\section{Maya Fitria Ningsih ${ }^{1}$, Ketut Sarjana ${ }^{2}$, Syahrul Azmi², Baidowi $^{2}$}

\author{
${ }^{1}$ Mahasiswa Pendidikan Matematika, Universitas Mataram, Mataram, Indonesia \\ 2 Pendidikan Matematika, Universitas Mataram, Mataram, Indonesia
}

*Corresponding Author e-mail: mayafitrianingsih290398@gmail.com

Received: 27-01-2021; Revised: 25-03-2021; Published: 25-03-2021

\begin{abstract}
Purpose of this research is to know influence of learning independence on student mathematic study result in VIII grade in SMP Negeri 9 Mataram academic year 2020/2021. Types of research is Causal comparative Quantitative research or ex-post facto. The sample was selected using simple random sampling technique, obtained 39 students were taken 4 or 5 students from each class randomly spread over 8 classes in class VIII SMP Negeri 9 Mataram. Data collection in this study was carried out by providing a learning independence questionnaire in the research sample and documentation of mid-semester test scores obtained from mathematics subject teachers. The results showed that there was a positive correlation between learning independence and learning result, namely $a=0.610$. With the other catalyst, the correlation was in the strong category. The amount of the contribution of learning independence to the mathematics learning result of class VIII students of SMP Negeri 9 Mataram academic year 2020/2021 is 37.20\% and this is quite significant at the 0.05 significant level. This result can also be shown by the regression equation $\mathrm{Y}=19.187+0.523 \mathrm{X}$ where $\mathrm{Y}$ is the learning independence and $\mathrm{X}$ is the result of learning mathematics.
\end{abstract}

Keywords: learning independence, mathematic study result.

\begin{abstract}
Abstrak
Penelitian ini bertujuan untuk mengetahui pengaruh kemandirian belajar terhadap hasil belajar matematika siswa kelas VIII di SMP Negeri 9 Mataram tahun ajaran 2020/2021. Jenis penelitian kuantitatif kausal komparatif atau ex-post facto. Populasi penelitian adalah semua siswa kelas VIII SMP Negeri 9 Mataram sebanyak 251 siswa. Sampel dipilih menggunakan teknik Simple random sampling, diperoleh 39 siswa diambil 4 atau 5 siswa dari setiap kelas secara acak yang tersebar pada 8 kelas di kelas VIII SMP Negeri 9 Mataram. Pengambilan data dalam penelitian ini dilakukan dengan memberikan angket kemandirian belajar pada sampel penelitian dan dokumentasi data nilai ulangan tengah semester siswa yang diperoleh dari guru mata pelajaran matematika. Hasil penelitian menunjukkan bahwa ada korelasi positif antara kemandirian belajar dan hasil belajar yaitu $a=0,610$. Dengan kata lain, korelasinya berada dalam kategori kuat. Besarnya sumbangan kemandirian belajar terhadap hasil belajar matematika siswa kelas VIII SMP Negeri 9 Mataram tahun ajaran 2020/2021 sebesar 37,20\% dan ini cukup signifikan pada taraf signifikan 0,05. Hasil ini juga dapat ditunjukkan dengan persamaan regresi $\mathrm{Y}=19,187+0,523 \mathrm{X}$ dengan $\mathrm{Y}$ adalah kemandirian belajar siswa dan $\mathrm{X}$ adalah hasil belajar matematika siswa.
\end{abstract}

Kata Kunci: kemandirian belajar, hasil belajar matematika.

\section{Cara Mengutip}

Ningsih, M.F., Sarjana, K., Azmi, S., \& Baidowi. (2021). Pengaruh kemandirian belajar terhadap hasil belajar matematika siswa kelas VIII SMP. Griya Journal of Mathematics Education and Application, 1(1), 11-18. 


\section{PENDAHULUAN}

Tujuan dari pembelajaran matematika dalam kurikulum adalah agar siswa memiliki kemampuan sebagai berikut: (1) Meningkatkan Kemampuan intelektual, khususnya kemampuan berpikir tingkat tinggi siswa, (2) Membentuk kemampuan siswa dalam menyelesaikan sebuah masalah secara sistematis, (3) Memperoleh hasil belajar yang tinggi, (4) Melatih siswa dalam mengomunikasikan ide-ide, khususnya dalam karya ilmiah, dan, (5) Mengembangkan karakter (Kemendikbud, 2013). Namun pada kenyataannya tujuan kurikulum masih belum terealisasikan dengan baik. Hal ini ditunjukkan oleh rata-rata nilai dan ketuntasan dari hasil belajar siswa tergolong rendah.

Berdasarkan hasil observasi kelas dan wawancara yang dilakukan di SMP Negeri 9 Mataram diperoleh informasi bahwa terdapat masalah yang dihadapi dalam proses pembelajaran. Di mana saat pembelajaran berlangsung, siswa cenderung malas dalam mengerjakan soal-soal latihan, lebih memilih menyalin dan mengandalkan jawaban temannya daripada mencari penyelesaiannya sendiri, interaksi yang terjadi di dalam kelas adalah interaksi satu arah dan sebagian besar dari siswa terlihat tidak memperhatikan penjelasan guru,dan justru lebih memilih mengobrol dengan teman sebangku atau teman yang duduk di belakangnya, hanya sedikit siswa yang mau bertanya saat mengalami kesulitan, dan siswa cenderung diam/pasif dalam pembelajaran karena takut serta tidak yakin akan jawaban dan pendapatnya sendiri. Gejala-gejala yang dialami siswa di SMP Negeri 9 Mataram seperti terungkap diatas merupakan indikator-indikator dari kemandirian belajar. Masalahnya sekarang adalah "Bagaimana pengaruh kemandirian belajar terhadap hasil belajar matematika siswa kelas VIII SMP Negeri 9 Mataram?

Tahar \& Enceng (2006) menyatakan bahwa kemandirian belajar adalah kesiapan dari indivudu yang mau dan mampu untuk belajar dengan inisiatif sendiri, dengan atau tanpa bantuan pihak lain dalam hal penentu tujuan belajar, metode belajar, dan evaluasi hasil belajar. Kemandirian akan menunjukkan pada kemampuan psikososial yang mencakup kebebasan untuk bertindak, tidak bergantung dengan kemampuan orang lain, tidak terpengaruh lingkungan, dan bebas mengatur kebutuhan sendiri (Nurhayati, 2011). Seperti yang dikemukakan Slameto (2015) belajar merupakan suatu proses perubahan yaitu perubahan tingkah laku sebagai hasil dari interaksi dengan lingkungannya dalam memenuhi kebutuhan hidupnya.

Menurut Tahar \& Enceng (2006) kemandirian belajar yaitu proses ketika individu mengambil inisiatif sendiri, dengan atau tanpa bantuan orang lain, untuk mendiagnosis kebutuhan belajar, memformulasikan tujuan belajar, mengidentifikasi sumber belajar, memilih dan menentukan pendekatan strategi belajar, dan melakukan evaluasi hasil belajar yang dicapai Prayuda (2014) mengungkapkan kemandirian belajar wajib dimiliki oleh siswa, karena belajar merupakan tanggung jawab siswa itu sendiri. Siswa yang memiliki kemandirian belajar yang kuat akan lebih banyak belajar sendiri dengan bantuan seminimal mungkin dari orang lain dan memperoleh hasil belajar yang tinggi, 
karena itu siswa perlu memiliki kepercayaan diri yang kuat dalam kegiatan belajarnya. Kepercayaan diri yang kuat akan mendorong siswa untuk tidak lekas putus asa dalam menghadapi kesulitan dan terdorong untuk meningkatkan hasil belajanya.

Sudjana (2010) berpendapat,"hasil belajar adalah kemampuan-kemampuan yang dimiliki siswa setelah ia menerima pengalaman belajarnya". Sedangkan menurut Aunurrahman (2009) menjelaskan "Hasil belajar ditandai dengan perubahan tingkah laku, walaupun tidak semua tingkah laku merupakan hasil belajar, akan tetapi aktivitas belajar umumnya disertai perubahan tingakah laku". Penelitian yang dilakukan oleh

McCauley dan McClelland (Fidiana, Lutfi, Bambang, \& Pratiwi, 2012) "menunjukkan bahwa siswa yang memiliki nilai rata-rata hasil belajar tinggi memiliki tingkat kemandirian yang tinggi pula".

Berdasarkan latar belakang tersebut tujuan penelitian ini yaitu untuk mengetahui pengaruh kemandirian belajar terhadap hasil belajar matematika siswa kelas VIII SMP Negeri 9 Mataram tahun ajaran 2020/2021".

\section{METODE}

Penelitian ini dilaksanakan pada siswa kelas VIII SMP Negeri 9 Mataram. Metode penelitian yang digunakan adalah metode kausal komparatif atau ex-post facto yaitu mengkaji keterkaitan variabel bebas dan variabel terikat. Variabel yang diteliti yaitu kemandirian belajar siswa (X) dan hasil belajar matematika (Y). Populasi penelitiannya berukuran 251 siswa yang tersebar di 8 kelas yang homogeny pada SMP Negeri 9 Mataram. Sedangkan sampelnya berukuran 39 siswa diambil secara acak dimana setiap kelas diwakili oleh 4 atau 5 siswa. Intrumen penelitian yang digunakan adalah kuesioner (angket) dan dokumentasi. Data dokumentasi adalah nilai ulangan tengah semester yang diperoleh dari guru matematika.

Instrumen penelitian yang digunakan sudah valid ditinjau dari uji validitas isi. Sebagai validator ahli adalah Efan Yudha Winata, M. Psi. Psikolog, Dosen Psikologi Universitas Teknologi Sumbawa. Teknik analisis data yang digunakan dalam penelitian ini adalah teknik statistik deskriptif dan teknik infrensial yakni regresi linier sederhana dengan rumus (Sudjana, 2013):

$$
\begin{aligned}
\hat{Y} & =a+b X \\
a & =\frac{\sum Y \sum X^{2}-\sum X \sum X Y}{n \sum X^{2}\left(\sum X\right)^{2}} \\
b & =\frac{n \sum X Y-\sum X \sum Y}{n \sum X^{2}\left(\sum X\right)^{2}}
\end{aligned}
$$

Analisis statistik deskriptif digunakan untuk mendeskripsikan kemandirian belajar dan hasil belajar matematika siswa. Untuk mendeskripsikan kemandirian belajar dan hasil beajar tersebut maka diperlukan penyajian data melalui perhitungan mean, dan simpangan baku yang disajikan dalam Tabel 1. 
Tabel 1. Kategori Pensekoran

\begin{tabular}{cc}
\hline Interval Nilai & Kategori \\
\hline$X \geq M_{i}+S_{b i}$ & Tinggi \\
$M_{i}-S_{b i} \leq X<M_{i}+S_{b i}$ & Sedang \\
$X<M_{i}-S_{b i}$ & Rendah \\
\hline
\end{tabular}

Keterangan:

$x=$ Skor responden

$M_{i}=$ Mean ideal

$S b_{i}=$ Simpangan baku ideal

\section{HASIL DAN PEMBAHASAN}

\subsection{Analisis statistik deskriptif data hasil penelitian}

Pengolahan data hasil penelitian dilakukan dengan bantuan progran SPSS 21. Hasil pengolahan data dan analisis ststistik dan deskriptif data dapat dilihat pada Tabel 2 dan Tabel 3.

Tabel 2. Ringkasan Statistik Deskriptif Kemandirian Belajar

\begin{tabular}{cccc}
\hline Interval & Banyak Siswa & Persentase (\%) & Kategori \\
\hline $\boldsymbol{X} \geq \mathbf{1 0 8}$ & 24 & $61,54 \%$ & Tinggi \\
$72 \leq \boldsymbol{X}<\mathbf{1 0 8}$ & 15 & $38,46 \%$ & Sedang \\
$\boldsymbol{X}<\mathbf{7 2}$ & 0 & $0 \%$ & Rendah \\
\hline
\end{tabular}

Hasil angket kemandirian belajar yang dilakukan terhadap 39 orang responden diperoleh mean atau nilai rata-rata jawaban responden adalah sebesar 121,51. Hal ini mengindikasi bahwa kemandirian siswa dalam belajar matematika berkecenderungan positif dan menunjukan angka yang cukup tinggi. Sementara ini nilai maksimum dan nilai minimum masing-masing adalah 140,00 dan 88,00.

Tabel 3. Ringkasan Statistik Deskriptif Hasil Belajar

\begin{tabular}{cccc}
\hline Interval & Banyak Siswa & Persentase (\%) & Kategori \\
\hline $\boldsymbol{X}>\mathbf{9 0}$ & 7 & $17,95 \%$ & Sangat tinggi \\
$\mathbf{8 0}<\boldsymbol{X} \leq \mathbf{9 0}$ & 8 & $20,52 \%$ & Tinggi \\
$\mathbf{7 0}<\boldsymbol{X} \leq \mathbf{8 0}$ & 12 & $30,77 \%$ & Cukup \\
$\mathbf{6 0}<\boldsymbol{X} \leq \mathbf{7 0}$ & 6 & $15,38 \%$ & Kurang \\
$\boldsymbol{X}<\mathbf{6 0}$ & 6 & $15,38 \%$ & Sangat Kurang \\
\hline
\end{tabular}

Data hasil UTS (Ulangan Tengah Semester) yang dilakukan terhadap 39 orang responden diperoleh nilai mean atau rata-rata jawaban responden siswa adalah sebesar78,03. Hal ini mengindikasi bahwa hasil belajar siswa dalam belajar matematika berkecenderungan positif dan menunjukan angka yang cukup tinggi. Sementara ini nilai maksimum dan nilai minimum dari masing-masing adalah 100,00 dan 57.

Berdasarkan hasil analisis statistik deskriptif untuk kemandirian belajar siswa SMP Negeri 9 Mataram tahun pelajaran 2020/2021 menunjukkan bahwa terdapat $61,54 \%$ siswa dikategorikan tinggi, $38,46 \%$ siswa berkategori sedang, dan $0 \%$ siswa dikategorikan rendah. Sedangkan, hasil analisis statistik deskriptif untuk hasil belajar 
matematika siswa SMP Negeri 9 Mataram tahun pelajaran 2020/2021 menunjukkan bahwa terdapat $84,62 \%$ siswa dikategorikan tinggi, $15,38 \%$ siswa berkategori sedang, dan 0\% siswa berkategori rendah. Berdasarkan hasil analisis statistik deskriptif dari kedua variabel menunjukkan bahwa kemandirian belajar siswa berbanding lurus dengan hasil belajar matematika siswa, dimana kedua variabel tersebut dapat digolongkan dalam kategori baik/tinggi yang mengindikasikan adanya hubungan antara kedua variabel tersebut.

\subsection{Analisis statistik inferensial}

Pengujian hipotesis dan analisis data dilakukan dengan bantuan SPSS 21. Hasil pengujian hipotesis dapat dilihat pada Tabel 4, Tabel 5, dan Tabel 6.

Tabel 4. Hasil Analisis Regresi Sederhana dan Perhitungan Uji $T$

\begin{tabular}{|c|c|c|c|c|c|}
\hline \multicolumn{6}{|l|}{ Coefficients } \\
\hline \multirow[t]{2}{*}{ Model } & \multicolumn{2}{|c|}{$\begin{array}{l}\text { Unstandardized } \\
\text { Coefficients }\end{array}$} & \multirow{2}{*}{$\begin{array}{c}\text { Stand } \\
\text { ardize } \\
d \\
\text { Coeffi } \\
\text { cients } \\
\text { Beta }\end{array}$} & \multirow[t]{2}{*}{$\mathrm{t}$} & \multirow[t]{2}{*}{ Sig. } \\
\hline & B & $\begin{array}{l}\text { Std. } \\
\text { Error }\end{array}$ & & & \\
\hline (Constant) & 19.187 & 12.646 & & 1.517 & .138 \\
\hline $\begin{array}{l}\text { Kemandirian } \\
\text { belajar }\end{array}$ & .523 & .112 & .610 & 4.686 & .000 \\
\hline
\end{tabular}

a. Dependent Variable: Kemandirian Belajar

Berdasarkan hasil perhitungan data pada Tabel 4, diperoleh harga $t$ hitung sebesar 4,686 dan nilai $t$ tabel pada taraf signifikansi 5\% dengan derajat kebebasan dk $(\mathrm{N}-2)=37$ adalah 2,026 . Berdasarkan hal tersebut maka $t$ hitung $>t$ tabel atau nilai sig. $=0,05$ yang berarti Ho ditolak, maka dapat disimpulkan bahwa terdapat hubungan yang signifikan kemandirian belajar terhadap hasil belajar matematika siswa SMP Negeri 9 Mataram tahun ajaran 2020/2021.

Berdasarkan hasil perhitungan data pada Tabel 4, diperoleh nilai $a=19,187$ dan nilai $b$ $=0,523$ sehingga diperoleh persamaan regresi: $Y=19,187+0,523 X$. Koefisien arah regresi $b=0,523$ mempunyai harga yang positif. Ini berarti jika nilai kemandirian belajar siswa bertambah satu unit maka hasil belajar matematika siswa akan bertambah sebesar 0,523 dan jika berkurang satu unit nilai kemandirian belajar siswa maka hasil belajar matematika siswa akan berkurang sebesar 0,523. Selanjutnya melakukan uji $F$ untuk mengetahui keberartian regresi, apakah koefisien regresi dapat digunakan untuk memprediksi hasil belajar matematika siswa (Y) yang dipengaruhi oleh kemandirian belajar siswa $(\mathrm{X})$. 
Tabel 5. Hasil Perhitungan Uji $F$

\begin{tabular}{|c|c|c|c|c|c|c|}
\hline \multicolumn{7}{|c|}{ ANOVA } \\
\hline \multicolumn{2}{|c|}{ Model } & $\begin{array}{l}\text { Sum of } \\
\text { Squares }\end{array}$ & $\mathrm{df}$ & $\begin{array}{l}\text { Mean } \\
\text { Square }\end{array}$ & $\mathrm{F}$ & Sig. \\
\hline \multirow[t]{3}{*}{1} & Regression & 1961.829 & 1 & 1961.829 & 21.962 & .000 \\
\hline & Residual & 3305.146 & 37 & 89.328 & & \\
\hline & Total & 5266.974 & 38 & & & \\
\hline
\end{tabular}

a. Dependent Variable: Hasil Belajar

Berdasarkan hasil perhitungan data pada Tabel 5, diperoleh nilai $F$ hitung = 21,962 dan nilai $F$ tabel pada taraf signifikan $5 \%$ dengan derajat kebebasan pembilang (dk1) 1 dan penyebut (dk2) 37 adalah 4,11 . Karena nilai $F$ hitung $>F$ tabel dan nilai sig. $=0,05$, maka dapat disimpulkan bahwa koefisien regresi dari persamaan regresi $Y=19,187+0,523 X$ dapat digunakan untuk memprediksi hasil belajar matematika siswa (Y) yang dipengaruhi oleh kemandirian belajar siswa (X). Selanjutnya perhitungan koefisien korelasi untuk mengetahui besarnya hubungan antara kemandirian belajar siswa (X) terhadap hasil belajar matematika siswa (Y) dan besarnya kontribusi yang diberikan.

Tabel 6. Hasil Perhitungan Koefisien Korelasi

\begin{tabular}{ccccc}
\hline & \multicolumn{4}{c}{ Model Summary } \\
\hline Model & $\mathrm{R}$ & R Square & $\begin{array}{c}\text { Adjusted R } \\
\text { Square }\end{array}$ & $\begin{array}{c}\text { Std. Error of the } \\
\text { Estimate }\end{array}$ \\
\hline 1 & .610 & .372 & .356 & 9.45136 \\
\hline
\end{tabular}

a. Predictors: (Constant), Kemandirian Belajar Siswa

b. Dependent Variable: Hasil Belajar

Berdasarkan Tabel 6, diperoleh nilai $\mathrm{R}=$ 0,610 yang menunjukan terdapat korelasi yang kuat antara kemandirian belajar dengan hasil belajar matematika. Hal ini di dukung dengan nilai $\mathrm{R}$ Square = 0,372 atau koefisien determinannya 37,2\%. Artinya hasil belajar dipengaruhi oleh faktor kemandirian belajar sebesar 37,2\% dan faktor lainnya sebesar $62,8 \%$.

Berdasarkan hasil perhitungan menggunakan analisis statistik inferensial menunjukkan bahwa terdapat pengaruh yang signifikan kemandirian belajar terhadap hasil belajar matematika siswa SMP Negeri 9 Mataram tahun pelajaran 2020/2021, yang dapat ditunjukkan melalui perhitungan uji $F$ dan uji $T$. Hasil uji $F$ menunjukkan nilai $F$ hitung sebesar 21,962; dimana nilai $F$ hitung tersebut lebih besar dari $F$ tabel $=4$,11 yang berarti bahwa koefisien regresi dari persamaan regresi yaitu $Y=19,187+0,523 X$ dapat digunakan untuk memprediksi hasil belajar matematika yang ditinjau dari kemandirian belajar. Persamaan regresi tersebut diartikan bahwa jika kemandirian belajar siswa bertambah 1 satuan maka nilai hasil belajar matematika siswa bertambah sebesar 0,523; dan begitupun sebaliknya jika kemandirian belajar siswa berkurang 1 satuan maka nilai hasil belajar matematika siswa berkurang sebesar 0,523. Selain itu, dari hasil perhitungan uji $T$ diperoleh nilai $T$ hitung sebesar 4,686. Karena $T$ hitung $=4,686>T$ tabel $=2,026$ maka hal ini menunjukkan bahwa koefisien korelasi sebesar 0,610 
dinyatakan sangat signifikan atau terdapat hubungan yang signifikan kemandirian belajar terhadap hasil belajar matematika siswa SMP Negeri 9 Mataram tahun pelajaran 2020/2021. Hasil perhitungan koefisien korelasi sebesar 0,610 juga dapat menentukan seberapa kuat hubungan kemandirian belajar terhadap hasil belajar matematika siswa. Secara umum hubungan kemandirian belajar terhadap hasil belajar matematika siswa SMP Negeri 9 Mataram tahun pelajaran 2020/2021 termasuk dalam tingkat hubungan yang kuat. Tingkat hubungan yang kuat antar variabel dalam penelitian ini juga didukung oleh kontribusi atau persentase besar pengaruh yang diberikan oleh kemandirian belajar terhadap hasil belajar matematika siswa yakni 37,20\% yang berarti $62,80 \%$ dipengaruhi oleh faktor lain.

Berdasarkan hasil penelitian ini dapat dijelaskan bahwa secara umum siswa SMP Negeri 9 Mataram tahun pelajaran 2020/2021 menunjukkan terdapat pengaruh yang signifikan kemandirian belajar terhadap hasil belajar matematika siswa yang linear positif dengan makna bahwa apabila kemandirian belajar siswa positif, maka hasil belajar matematika siswa akan tinggi. Peranan kemandiriaan belajar dalam diri siswa diperlukan dalam kegiatan pembelajaran karena merupakan faktor internal yang mempengaruhi hasil belajar matematika siswa. Meskipun besarnya pengaruh yang diberikan kemandirian belajar tidak sebesar faktor lain yang mempengaruhinya, namun memberikan pengaruh yang signifikan terhadap hasil belajar matematika siswa yang nantinya juga mempengaruhi prestasi siswa. Hal ini ditunjukkan oleh motivasi yang kuat, inisiatif, rasa tanggung jawab, percaya diri dan aktif. Perilaku tersebut mengakibatkan siswa rajin dalam mengerjakan tugas yang diberikan, selalu berusaha dalam mengerjakan soal matematikan tepat waktu hadir mengikuti pelajaran matematika disekolah, insiatif dalam membuat rangkuman untuk mempermudah dalam belajarnya, serta aktif dsaat pemeblajaran berlangsung. Dengan demikian proses belajar siswa menjadi optimal, sehingga menyebabkan dampak positif pada hasil belajar matematika siswa. Dengan motivasi, insiatif, tanggung jawab, percaya diri, dan aktif dalam belajarnya maka siswa mampu memcapai tujuan belajar yang dicapai, mengusai suatu kompetensi tertentu sehingga membantunya mancapai hasil belajar yang lebih baik. Hal ini sesuai dengan apa yang dikemukakan oleh Fatimah (2010:142), kemandirian meliputi perilaku mampu berinisiatif, mampu mengatasi hambatana/masalah, mempunyai rasa percaya diri, dan dapat melakukan sesuatu sendiri tanpa bantuan orang lain. Seorang siswa yang mandiri dalam belajarnya memiliki kemampuan sendiri untuk belajar, mampu memecahkan masalah, mempunyai tanggung jawab, dan mempunyai rasa percaya diri dalam setiap proses belajarnya. Sedangkan menurut Mujiman (2007:45), kemandirian belajar dapat diartikan sebagai sifat serta kemampuan yang dimiliki siswa untuk melakukan kegiatan belajar aktif, yang didorong motif untuk menguasai kompetensi yang telah dimiliki. Siswa yang mandiri dalam belajarnya memiliki tujuan yang dicapai, kemudian menyusun rencana untuk mencapai tujuan tersebut, merencanakan, dan mengevaluasi diri untuk mengetahui perkembangan apa yang sudah diperoleh serta memperbaiki hal yang kurang dipahami. Hasil penelitian ini sejalan dengan penelitian yang dilakukan oleh Egok (2017) yang menunjukkan adanya pengaruh yang signifikan dan hubungan yang kuat antara kemandirian belajardan hasil belajar kelas V di SDN Sirnagalih Gugus I Kecamatan Taman Sari Kota Bogor. Serta hasil penelian yang dilakukan oleh Kurnia, 
dkk (2019) yang menunjukan terdapat pengaruh positif yang signifikan kemandirian belajar terhadap hasil belajar matematika, besar sumbangan kemandirian belajar terhadap hasil matematika sebesar $16 \%$ dan sisanya $84 \%$ disumbang oleh variabel lain selain kemandirian belajar.Hal ini juga sesuai dengan pendapat Ariska (2016:94) bahwa keyakinan terhadap kemandirian diyakini dapat mempengaruhi prestasi belajarnya.

Dapat diartikan bahwa kemandirian belajar yang positif dapat mempengaruhi prestasi belajarnya, sehingga dapat membentuk karakter siswa yang lebih mampu merespon positif setiap perubahan. Karakter siswa yang dimaksudkan adalah memiliki motivasi yang kuat, berinisiatif tinggi, percaya diri yang tinggi, dapat bertanggung jawab, dan aktif untuk merencanakan, melakukan, mengevaluasi dirinya. Untuk itu, kemandirian belajar dan hasil belajar dapat dikatakan saling berhubungan satu sama lain dan merupakan sinergi bagi keberlangsungan serta ketercapaian tujuan kurikulum dalam pendidikan.

\section{PENUTUP}

Kemandirian belajar yang dimiliki siswa SMP Negeri 9 Mataram tahun ajaran 2020/2021 terdapat $61,54 \%$ siswa dikategorikan tinggi, 38,46\% siswa berkategori sedang, dan $0 \%$ siswa dikategorikan rendah. Sedangkan hasil belajar matematika terdapat $60,23 \%$ siswa dikategorikan tinggi, 30,77\% siswa berkategori sedang, dan 0\% siswa berkategori rendah. Terdapat pengaruh yang signifikan kemandirian belajar terhadap hasil belajar matematika siswa SMP Negeri 9 Mataram tahun ajaran 2020/2021. Hal ini ditunjukkan oleh perhitungan $\mathrm{F}$ hitung $=21,962>\mathrm{F}$ tabel $=4,11$ yang berarti koefisien regresi dari persamaan regresi $\mathrm{Y}=19,187+0,523 \mathrm{X}$ dapat digunakan untuk memprediksi hasil belajar matematika yang dipengaruhi oleh kemandirian belajar. Besarnya korelasi antara kemandirian belajar dengan hasil belajar adalah 0,610 besaran ini sangat signifikan atau terdapat hubungan yang signifikan kemandirian belajar terhadap hasil belajar matematika siswa, dimana termasuk dalam tingkat hubungan yang kuat karena diperoleh harga $\mathrm{t}$ hitung $=4,686>\mathrm{t}$ tabel $=2,026$. Besarnya pengaruh yang diberikan oleh kemandirian belajar terhadap hasil belajar matematika siswa SMP Negeri 9 Mataram tahun ajaran 2020/2021 adalah sebesar 37,20\%.

\section{REFERENSI}

Aunurrahman. (2009). Belajar dan pembelajaran. Bandung: Alfabeta.

Fidiana, Lutfi, Bambang, S., \& Pratiwi, D. (2012). Pembuatan dan implementasi modul praktikum fisika berbasis masalah untuk meningkatkan kemandirian belajar siswa kelas XI. Unnes Physics Education Journal, 1(1), 39-43.

Kemendikbud. (2013). Kerangka dasar dan struktur kurikulum 2013. Jakarta: Kemendikbud.

Nurhayati, E. (2011). Psikologi pendidikan inovatif. Cirebon: Pustaka Remaja.

Prayuda, R. (2014). Pengaruh kemandirian belajar dan perhatian orang tua terhadap prestasil belajar matematika. Universitas Tanjung Pura.

Slameto. (2015). Belajar dan faktor-faktor yang mempengaruhi. Jakarta: Rineka Cipta.

Sudjana, N. (2010). Penilaian hasil proses belajar mengajar. Bandung: PT. Remanaj Rosdakarya. Sudjana, N. (2013). Teknik analisis regresi dan korelasi bagi peneliti. Bandung: Tarsito.

Tahar, I., \& Enceng. (2006). Hubungan kemandirian belajar dan hasil belajar pada pendidikan jarak jauh. Jurnal Pendidikan Terbuka Dan Jarak Jauh, 7(2), 91-101. 